\title{
The influence of the extraction method on the DNA protective effects of seaweed extracts in Caco-2 cells
}

\author{
A. M. O’Sullivan ${ }^{1}$, Y. C. O’Callaghan ${ }^{1}$, M. N. O'Grady ${ }^{1}$, M. Hayes ${ }^{2}$, J. P. Kerry ${ }^{1}$ and N. M. O’Brien ${ }^{1}$ \\ ${ }^{1}$ School of Food and Nutritional Sciences, University College Cork and ${ }^{2}$ Teagasc Ashtown Food Research Centre, Ashtown, \\ Ireland
}

Brown seaweeds contain a variety of compounds such as phlorotannins, carotenoids, vitamins, phospholipids and peptides that may benefit human health ${ }^{(1)}$. The extraction method and type of solvent used influences the nature of compounds extracted from seaweeds ${ }^{(2)}$. The solvents in the present study (water, ethanol and methanol) are of a polar nature and extract a range of hydrophilic compounds including the phlorotannins.

The objective of the present study was to determine the potential protective effect of extracts obtained from Ascophyllum nodosum (AN) and Fucus serratus (FS) against hydrogen peroxide $\left(\mathrm{H}_{2} \mathrm{O}_{2}\right)$ and tert-butylhydroperoxide (tert-BOOH)-induced DNA damage in Caco- 2 cells. Compounds were extracted using $100 \% \mathrm{H}_{2} \mathrm{O}, 60 \%$ ethanol $(\mathrm{EtOH})$ or $60 \%$ methanol $(\mathrm{MeOH})$. Caco- 2 cells were pre-treated with each seaweed extract for $24 \mathrm{~h}$ followed by exposure to either $50 \mu \mathrm{M} \mathrm{H}_{2} \mathrm{O}_{2}$ or $200 \mu \mathrm{M}$ tert-BOOH for 30 min. DNA damage was assessed by the comet assay.

\begin{tabular}{|c|c|c|c|c|}
\hline & \multicolumn{2}{|c|}{ tert-BOOH ( $\%$ tail DNA) } & \multicolumn{2}{|c|}{$\mathrm{H}_{2} \mathrm{O}_{2}(\%$ tail DNA $)$} \\
\hline & Mean & SE & Mean & SE \\
\hline Control & 10.0 & 2.0 & 10.0 & 2.0 \\
\hline Positive control & 30.0 & 3.5 & 55.0 & 3.0 \\
\hline $\mathrm{AN}\left(100 \% \mathrm{H}_{2} \mathrm{O}\right)$ & 20.5 & 2.0 & $35.0 \#$ & 6.0 \\
\hline $\mathrm{AN}(60 \% \mathrm{EtOH})$ & $18.5 \#$ & 1.0 & 46.0 & 3.0 \\
\hline $\mathrm{AN}(60 \% \mathrm{MeOH})$ & 30.5 & 1.5 & 61.0 & 1.0 \\
\hline FS $\left(100 \% \mathrm{H}_{2} \mathrm{O}\right)$ & $17.5^{\dagger}$ & 1.5 & 47.0 & 5.5 \\
\hline FS $(60 \% \mathrm{EtOH})$ & 21.5 & 2.5 & 48.0 & 2.0 \\
\hline $\mathrm{FS}(60 \% \mathrm{MeOH})$ & 26.0 & 1.5 & 45.0 & 5.5 \\
\hline
\end{tabular}

The addition of $50 \mu \mathrm{M} \mathrm{H}_{2} \mathrm{O}_{2}$ and $200 \mu \mathrm{M}$ tert-BOOH increased the DNA damage in Caco-2 cells to 55 and $30 \%$, respectively. Preincubation of Caco-2 cells with AN $(60 \% \mathrm{EtOH})$ and $\mathrm{FS}\left(100 \% \mathrm{H}_{2} \mathrm{O}\right)$ extracts offered significant protection against tert-BOOHinduced DNA damage. Only the $\mathrm{AN}\left(100 \% \mathrm{H}_{2} \mathrm{O}\right)$ extract significantly reduced $\mathrm{H}_{2} \mathrm{O}_{2}$-induced DNA damage. The MeOH extracts of AN and FS did not protect against either $\mathrm{H}_{2} \mathrm{O}_{2}$ or tert-BOOH-induced DNA damage. The DNA protective effects of the seaweeds may indicate their potential use in the pharmaceutical and functional food industry. The presence of hydrophilic polysaccharide compounds may account for the antioxidant ability of the $100 \% \mathrm{H}_{2} \mathrm{O}$ extracts, whereas the antioxidant behaviour of the aqueous ethanol extracts may be due to the presence of a mixture of polar and less polar compounds.

Funding for this research was provided under NutraMara. The Marine Functional Foods Research Initiative (NutraMara project) is a programme for marinebased functional food development established by the Marine Institute and the Department of Agriculture, Fisheries and Food (DAFF). It is supported by funds provided under the Strategy for Science, Technology and Innovation 2006-2013 (SSTI) and the Food Institutional Research Measure (FIRM), to establish a Marine Functional Foods Research Programme.

1. Shahidi F (2009) Trends Food Sci Tech 20, 376-387.

2. Shanab SMM (2007) IJAB 9, 220-225. 